\title{
Expert Views on the Causes and Solutions of the Doping Issue in Turkey's Sports
}

\section{Türkiye'de Sporda Dopingin Nedenleri ve Çözüm Yollarna Dair Uzman Görüşleri}

\author{
Sait Tarakçıoğlu \\ Psychosocial Fields in Sports, Department of Physical Education Teaching, \\ Faculty of Sport Sciences, Ege University, Izmir, Turkey
}

S. Tarakçı̆̆ 0000-0002-7895-6040

Geliş Tarihi/Date Received: 13.06.2019

Kabul Tarihi/Date Accepted: 29.08.2019

Yayın Tarihi/Published Online: 30.10.2019

Yazışma Adresi /

Corresponding Author:

Sait Tarakçıŏglu

Ege Üniversitesi , Beden Eğitimi Öğretmenliği Bölümü, Sporda Psikososyal Alanlar, İzmir, Turkey

E-mail:

sait.tarakcioglu@gmail.com

(C)2020 Türkiye Spor Hekimleri Derneği. Tüm hakları saklıdır.

\section{ABSTRACT}

Objectives: The purpose of the research is to deal with the causes and solutions of increasing doping issues in Turkey's sports in compliance with the view of experts.

Methods: In this qualitative research, a purposeful sampling technique was used to identify the thirteen experts that were asked to be interviewed for the project. After a comprehensive literature review, the semi-structured questions were prepared for the interviews. The three questions were regarding the causes of the doping issue in Turkey's sports, the possible solutions, and the actors who are supposed to deal with the so-called problem. The individual interviews were carried out between August of 2018 and April of 2019 in İzmir and İstanbul, and tape-recorded with prior permission of the participants. Data obtained from the interviews were evaluated by descriptive content analysis.

Results: Upon descriptive content analysis, five main categories were identified about the doping issue in Turkey's sports. They are, in turn, lack of a proper education, extremely high awards, sport culture, inadequate doping control mechanisms, and bad sport management in Turkey.

Conclusion: The doping issue in Turkey's sports can be solved with common struggle of state institutions. With this regard, the athletes, sport managers, coaches and teachers should have an extensive education about the harms and moral issues of doping use. Furthermore, the number of doping controls should be raised; high monetary awards should be leveled to reasonable amounts, in assignments of sport managers proper competency should be regarded, and there should be a mechanism controlling the relationships between athletes and coaches.

Keywords: Turkey, sports, doping

öz

Amaç: Bu çalışmanın amacı, Türkiye'de son yıllarda artış gösteren doping vakalarının nedenlerini ve çözüm önerilerini uzman görüşleri ışığında ortaya koymaktır.

Gereç ve Yöntem: Araştırmada, nitel araştırma yöntemlerinden görüşme yöntemi kullanılmaktadır. Buna göre, sporda doping konusunda uzman olduğu düşünülen 13 kişi amaçlı örneklem yöntemiyle seçilmiştir. Bu yöntem, seçilen sorun hakkında bilgisi ve deneyimi olduğu düşünülen kişilerin saptanması ve seçilmesi işleminden oluşmaktadır. Ayrıntılı bir literatür taramasının ardından ortaya çıkan bulgular ışığında, uzmanlara yöneltilecek sorular yarı yapılandırılmış olarak hazırlanmıştır. Türkiye'de sporda dopingin nedenleri, nasıl engellenebileceği ve hangi kurum, kuruluş ve kişilerin bu süreçte rol alması gerektiğine dair üç sorudan oluşan görüşmeler, birebir ve yüz yüze yapılarak, katılımcıların da izniyle elektronik ortama kaydedildi. Görüşmeler Ağustos 
2018 ve Nisan 2019 arasında, İzmir ve İstanbul'da gerçekleştirildi. Görüşmelerden elde edilen veriler tanımlayıcı içerik analizine tabi tutuldu.

Bulgular: Analizler neticesinde Türkiye'de doping kullanımının yaygınlaşmasının nedenleri beş ayrı kategoriye ayrıldı. Bunlar; bilgisizlik, yüksek ödüller, spor kültürü, denetimlerin eksikliği ve kötü yönetimler olarak karşımıza çıkmaktadır.

Sonuç: Türkiye'deki doping sorunu devletin ilgili tüm kurumlarının ortak mücadelesiyle çözülebilir. Bu kapsamda, sporcuların, antrenörlerin ve yöneticilerin dopingin zararları ve sporda yarattığı ahlaki problemlere dair sürekli bir eğitimden geçmeleri; doping kontrollerinin arttırılması; yüksek ödüllerin makul seviyelere çekilmesi; spor yönetiminde liyakate bakılması ve antrenör ile sporcu ilişkisini denetleyen bir mekanizmanın kurulması gerekmektedir.

Anahtar Sözcükler: Türkiye, spor, doping

Available at: http://journalofsportsmedicine.org and http://dx.doi.org/10.5152/tjsm.2020.172

Cite this article as: Tarakcioglu S. Expert views on the causes and solutions of the doping issue in Turkey's sports. Turk $J$ Sports Med. 2020;55(2):156-64.

\section{GÍRİS}

Adil bir yarışma imkanını ortadan kaldıran, sporcuların hayatını tehdit eden ve seyircileri spordan uzaklaştıran doping, dünya sporunun en büyük sorunu olarak hala yerini korumaktadır. Doping, elit sporun başlangıcından beri kullanıldığ iddia edilmekle birlikte $(1,2)$ birçok sporcunun ölümüne ya da sağlı̆̆ının önemli derecede bozulmasina neden olmuştur. Buna karşın, dopingle mücadele de ciddi bir şekilde yürütülmektedir. Dünya Anti Doping Ajansı (WADA) ve ilgili ülke kurumları bu sorunun çözümüne yönelik ortak adımlar atsa da, spordaki doping kullanımını tamamen yok etmek şimdilik mümkün görünmemektedir. Öyle ki, İngiliz doktor Michael Turner, 1996 Atlanta Olimpiyatlarına katılan atletizm yarışmacıları ile ilgili yaptığı araştırma sonucunda, sporcuların \%75'inin doping kullandığını söylemiştir (3).

$\mathrm{Bu}$ konuda, özellikle atletizm, halter ve güreş gibi sporlarda doping vakalariyla sarsilan ve bazı milli takımları uluslararası yarışmalardan bir süre men edilmesine kadar varan Türkiye'nin durumu pek iç acıcı değildir. Dopingle ilişkisinde sicili kötü görünen Türkiye'de, antidoping mücadelesi Türkiye Dopingle Mücadele Komisyonu (TDMK) öncülügünde yürütülmektedir. TDMK, 2011 yılında kurulduğunda, vizyonunu, "Bütünüyle dopingi reddeden ve etik değerlere bağlı bir spor camiasının oluşmasına yardımcı olmak ve Türk sporunu her seviyede dopingden arındırmak." olarak belirlemiştir (4). $\mathrm{Bu}$ amacın tam anlamıyla başarıya ulaşmadığ açıktır; bunun yanı sıra, sadece yarışma spor- larındaki mücadeleyi kapsamaktadır. Çeșitli spor salonlarında, yarıșma amacı gütmeden ve genellikle estetik kaygılarla yapılan fiziksel aktivitelerdeki doping kullanımını da içeren bir mücadele henüz söz konusu değildir.

Türkiye'de sporu uluslararası düzeyde olumsuz etkileyen, çocuk ve gençlerin sağlığını ciddi bir şekilde riske atan bu sorunun çözümüne yönelik akademik çalıșmalar yok denecek kadar azdır. Yapılacak çalışmaların Türkiye'de anti-doping mücadelesine katkıda bulunacağı ve akademisyenlerin bu alana yönelmeleri açısından farkındalık yaratacağı söylenebilir. Bu nedenle, uzmanlarla gerçekleştirilen bu araştırma, Türkiye'deki doping sorununa dikkat çekmeyi ve konuya dair çözüm önerileri sunmayı amaçlamaktadir.

\section{GEREÇ ve YÖNTEM}

Bu araştırmada Türkiye'deki doping sorunu nedenleri ve çözüm önerileriyle birlikte ele alınmaktadır. Araştırmada nitel araştırma yöntemi kullanıldı. Buna göre, sporda doping konusunda uzman olduğu düşünülen 13 kişi amaçlı örneklem $(5,6)$ yöntemiyle seçildi. Bu yöntem, seçilen sorun hakkında bilgisi ve deneyimi oldugu düşünülen kişilerin saptanması ve seçilmesi işleminden oluşmaktadır (5). Uzmanların sayısının belirlenmesinde; deneyim ve bilgilerinin yanı sıra, ulaşılabilir olmaları, görüşmenin yapılacağı tarihlerde uygun olmaları ve görüşmeyi kabul edecek olmaları etkili oldu. Uzmanlar, milli takım antrenörleri, üniversite öğretim 
üyeleri ve Türkiye'de anti-doping mücadelesinde üst düzey görevler almış spor hekimlerinden oluşmaktadır. Ayrıntılı bir literatür taramasının ardından ortaya çıkan bulgular ışığında, uzmanlara yöneltilen sorular yarı yapılandırılmış olarak hazırlandı.

Görüşmeler Ağustos 2018 ve Nisan 2019 arasında, İzmir ve İstanbul'da gerçekleştirildi. Türkiye'de sporda dopingin nedenleri, nasıl engellenebileceği ve hangi kurum, kuruluş ve kişilerin bu süreçte rol alması gerektiğine dair üç sorudan oluşan görüșmeler, bire bir ve yüz yüze yapılarak, uzmanların da izniyle elektronik ortama kaydedildi. Uzmanlara görüşmeler öncesi, Bilgilendirilmiş Onam Formu onaylatıldı. Kaydedilen veriler yazıya döküldükten sonra araştırmacı tarafından tanımlayıcı içerik analizine tabi tutuldu. Yazı dosyaları nitel araştırma yönteminde uzman olan iki ayrı akademisyene de inceletilerek, analiz için gerekli kod ve temaların oluşturulması tamamlandı (7). Ortaya çlkan kodlar ve temalar sonucunda araştırmanın yazım aşamasına geçildi. Çalışmada uzmanlardan bahsedilirken " $U$ " harfi ve bitișiğinde birer rakam kullanıldı.

\section{BULGULAR}

Analizler neticesinde, Türkiye'de doping kullanımının yaygınlaşmasının nedenleri beş ayrı kategoriye ayrıldı. Bunlar; bilgisizlik, yüksek ödüller, spor kültürü, denetimlerin eksikliği ve kötü yönetimler olarak aşağıda ele alınmaktadır.

\section{Bilgisizlik}

Uzmanların çoğu, ülkemizdeki doping kullanımının başlıca nedenlerinden birinin bilgisizlik olduğunu vurgulamaktadır. Sporcular dopingin ölümcül olabilecek zararlarından habersizken, dopingin yarattığ eşitsizlikler konusunda da herhangi bir eğitimden geçmemektedirler. Böylece hem kendi bedenini korumayan hem de ahlaki bir duruştan yoksun bu sporcular dopinge başvurmaktadırlar. Uzmanların görüşleri aşağıdaki gibidir:

"Sporcular bilinçsizce kullanıldığında çok vahim sonuçların ortaya çıkacağının idrakinde değiller. Bazıları biraz idrak etse de bunu kabullenmiş durumda..." (U3).
"Sporda ahlaki gelişimin, karakter gelişiminin yeterince işlenmemesinin, kişilere bunun altyapılardan itibaren kazandırılmamasının da etkili olduğunu düşünüyorum." (U4).

"Bir gün bir liseye beni çağırdılar, orada bir konferans verdim. Çocuklar diyorlar ki, bu doping olmadan biz başarılı olamayız. İnandırılmışlar. 0 okullara doping dersleri konmalı ve zararları anlatılmalı." (U5).

Uzmanların önemli bir kısmı, antrenörlerin de hem mesleki bilgi hem de dopingin zararları hakkında aşırı derecede bilgisiz olduklarını vurguladılar. Onlara göre bu bilgisizlik Türkiye'de dopingin başlıca nedenlerindendir.

"Dopingin yaygınlaşmasının başlıca nedenlerinden biri, genel müdürlüğün verdiği, eğitime ters düşen birkaç haftalık antrenörlük kurslarıyla, aslında çok derinlemesine bilinmesi gereken bilgilerin antrenör adaylarına aktarılamaması sonucunda, bilinçsiz, yeterliliği olmayan antrenörlere sporcularımızın teslim edilmesidir... Bu antrenörler, dopingsiz olmaz, demeye başliyorlar." (U8).

"Şimdiki antrenörler de dopinge bu kadar önem verdikleri ve bu ișin mutlaka dopingle olacağına inandıkları için -tabii bütün antrenörlere söylemiyorum, yapanlara söylüyorum-, onlar da kendi mesleki bilgilerini öğrenmek istemiyorlar. Mesela, antrenör oturup da antrenman teorisi, fizyoloji, biyomekanik öğrenmek istemiyor. Onun yerine başarılı olacağını düşündüğü için doping konusunu öğrenmeye çalışıyor, bunu da yalan yanlış kulaktan dolma öğrenip sporcularına uyguluyor..." (U3).

\section{Prim ve Ödül Sistemi}

Görüşmeye katılan uzmanlar, sporcuların aldığı yüksek ödüllerin dopingin yaygınlaşmasında önemli bir rolü olduğunu savunmaktadır. Uzmanlar, büyük parasal ödüllerin, özellikle ekonomik açıdan alt sınıftan gelen sporcuları ve onların antrenörlerini rekabetin çok yoğun olduğu spor atmosferinde dopinge doğru ittiğini düşünmektedir. Dahası, bazı branşlarda diğer ülkelere oranla Türkiye'nin çok yüksek maddi ödüller vermesinin gelecekteki doping skandallarına 
da kapı araladığını iddia etmektedirler. Uzman görüşleri aşağıdaki gibidir:

"En büyük neden devletin sporu teşvik yönetmeliği adı altında vermiş olduğu ödüldür. Çünkü bu yönetmelik insanların, bir anlamda 'kısa yönden madalya kazanayım, kısa yoldan köșeyi döneyim' mantığını besliyor... 1000 cumhuriyet altını!" (U11).

"Kişilerin ekonomik şartları kötüye gittiği zaman ve ekonomik çıkarlar elde etmek istedikleri zaman, ahlaki açıdan değerlendirmeleri de kötüye gidebilir. Bunun dünyada çok değişik örnekleri var, sadece doping Türkiye'nin bir konusu da değil. Bu 'ne pahasına olursa olsun kazanmanın' mutlak hale getirilişinin, sporun yarışmacı karakterinin ve de ekonomik çıkar elde etme yönünün, sporun bir rant, bir ekonomi, bir siyaset, bir endüstri haline getirilișinin de bunda önemli etkilerinin olduğunu düşünüyorum." (U4).

"Bir șey daha var onları buraya iten, hem sporcuyu hem de antrenörü: ödül kısmı. 0 da motive etmek için konmuş çok güzel bir şey ama iyi kontrol edilmediğinde böyle kötü motive ediyor. Adam ödül için şunu söylüyor 'ben alırım ilacı, dereceyi koşarım, ödül neyse işte, ev, şu bu alırım. Ondan sonra başıma bir şey gelecekse de gelsin." (U3).

"Dünyanın hiçbir yerinde bizdeki kadar yüksek oranda paraların verildiğini görmüyoruz. Yani veren birkaç yer var olabilir, ama ben kendimizi kıyasladığımız ülkelere baktığımda, hiçbirisi bize yaklașmıyor. Bizim futbolcumuzun, basketçimizin, atletimizin, haltercimizin aldı ğı para benzer seviyelerdeki futbolcunun, basketçinin, haltercinin ya da atletin aldığı paranın çok çok üstünde." (U11).

\section{Spor Kültürü}

Uzmanlar; sporcuların, herkesin doping kullandığına, dolayısıyla doping kullanmadan başarıya ulaşılamayacağına inandıklarını belirtmektedir. Genellikle antrenörlerinden, hekimlerinden, arkadaşlarından, yarışma ortamındaki diğer sporculardan ve basından edindikleri bu inanış nedeniyle kendileri de dopinge yönelmektedirler. Örneğin, U1, sporcuların şöyle düşündüğünü savunmaktadır:
"Mesela diyor ki sporcu, 'karşı takımda rakibim olan sporcu doping kullanıyor, onunla eşit seviyeye gelmem için benim de doping kullanmam lazım." U1 dopingin yaygınlığına dair ise şunları belirtmektedir:

"Her türlü yarışa katılan birçok sporcu doping kullanıyor, yakalanmıyor. Çünkü arkalarında çok büyük bir ekip var. İşte doktoru, kimyageri, kimya mühendisi, biyoloğu belki eczacısı... Büyük bir ekip var, ilaçlar ne kadar sürede vücuttan atılıyor, bunu müsabakalara gitmeden önce gayet güzel deniyorlar, ne kadar sürede elimine ediliyor, idrar ve kan testleriyle bunlara bakıyorlar." (U1).

'Beni kimse görmüyorsa, yaptığım doğrudur' anlayışı; ve doping de buna uyuyor. Kişilerin, onları gören birisi olmadığında her şeyi doğru ve kendilerine mubah görmeleri biraz Makyavelizm'le de ilişkilendirilebilir." (U4).

Bunun yanı sıra U1 ve U3, doping kullanımında antrenörün etkisinden bahsetmektedir: "Sporcu bu süreci antrenörüyle birlikte planlıyor. Çünkü hiçbir sporcu antrenöründen destek almadan bu ilaçları kullanamaz. Çünkü antrenmanların yetersiz olduğunu düşünüyorlar." (U1).

"Bir gün bizim kapalı spor salonunda yarışmalar vardı. Benim antrenör olmama sebep olan hocam geldi Ankara'dan. 0 da tıp profesörü... Federasyon başkanlığı da yaptı. Beni gördü. Merhabalaştık. 'Sen hala antrenörlük yapıyor musun?' dedi. 'Yapıyorum' dedim. 'Oğlum birak bu işi' dedi. 'Niye' dedim. 'Bizim misyonumuz bitti artık oğlum' dedi. 'Niye, ağabey' dedim. 'Yahu bu antrenörler öyle ilaçlardan bahsediyorlar ki ben tıp profesörüyüm ben bilmiyorum bu ilaçları' dedi. 'Bu nedir, bu hale gelmiş spor' dedi. 'Bırak bu iși' dedi, ben de bıraktım." (U3).

U12 ise, dopingin spor kültürünün bir parçası olduğunu ve Türkiye'nin, eğer bașarılı olmak istiyorsa, dopingin daha iyi yapılmasını ve yakalanmamasını sağlayacak çalışmalara ağırlık vermesi gerektiğini savunmaktadır. Ona göre, "dünyadaki neredeyse tüm ülkelerin sporcuları doping kullanmaktadır ve Türkiye'nin kendi sporcularının doping kullanmasını engellemesi haksız rekabet doğuracaktır. Kısacası Türki- 
ye'nin sporcuları başarılı olmak istiyorlarsa doping kullanmak zorundadır." U11'in dopingin yaygınlığı konusunda söyledikleri de yukarıdaki açıklamayı kısmen doğrulamaktadır: "Herkes doping olduğunu biliyor. Ama hiç kimse doping olduğunu söylemiyor... Herkes kamplarda doping kullanıldığını biliyor. Oraya giden kafile başkanları da biliyor ama yokmuş gibi yapiliyor."

\section{Kontrol Eksikliği}

Katılımcılardan bazıları Türkiye'deki doping kontrollerinin artmasıyla doping kullanan sporcuların ve vakaların daha görünür hale geldiğini vurgularken, bazıları ise denetimlerin yetersiz olduğunu ve daha etkin bir mücadelenin şart olduğunu söylemektedir. Özellikle yarışma sporları dışında fitness merkezlerinde gençlere satılan ilaçların önüne geçilmediği takdirde çok acı sonuçlarının doğacağı da belirtilmektedir. U5 yaptırımların caydırıcılığının olmadığına inanmaktadır. U11'e göre ise, "Türkiye'nin dopingle mücadelesi de 'mış gibi yapma' üzerine kurulu, bütün bunların da değiștirilmesi lazım."

Katılımcıların çoğu denetimlerin yetersiz olduğunu düşünse de; U9, Türkiye'deki anti-doping mücadelenin artmasından kaynaklı olarak, zaten yaygın olan doping kullanımının daha görünür hale geldiğini savunmaktadır. Özellikle, 20122013 yıllarındaki mücadele ile birçok dopingli sporcunun yakalandığını söylemektedir. Buna rağmen, yarışmaya katılma ve test edilme durumları olmadığından, çoğu spor salonu ve fitness merkezlerinde kontrolün neredeyse imkansız olduğunu ve buralarda doping kullanımının inanılmaz düzeylere ulaştığını vurgulamaktadır. Bunun da temelinde büyük bir ekonomi haline gelen ilaç sektörünün bulunduğunu dile getiren U9, buradan çok fazla insanın para kazandığını iddia etmektedir.

U6 ise, antrenör ve sporcu arasında var olan ilişkinin denetimsizliği üzerine şunları belirtmektedir: "Burada iyi oturmuş bir spor sistemi yok. Her şeyin kurumlar üzerinden değil kişiler üzerinden gittiği bir spor sistemi var. Kurumların denetleme mekanizmaları iyi çalışmıyor... Yani antrenör ve sporcu ilişkisi kurulurken bir denetleme mekanizması gerekiyor, bu ilişkinin içine dahil olacak. Sonuçta eğer elit spor kurumunun içinde bir performans gösteriyorsan, o kurumun çeşitli denetleme mekanizmalarına dâhil olman gerekir... Antrenör ve sporcu çok yalnız, bilhassa bireysel sporlarda. Dolayısıyla, o ilişki ve sporcunun alanla kurduğu ilişki kişisel ilișkiler üzerinden giden, gündelik, kulaktan dolma bilgilerle yürüyen ilişkiler... Şimdi, böyle bir yapının içinde performans arttırıcılarının denetimsiz bir şekilde kullanılmasına kolay bir zemin oluşturuyor böyle bir ilişki biçimi."

\section{Kötü Yönetimler}

Katılımclar, Türkiye'de dopingin yaygınlaşmasının bir diğer nedeni olarak da spor yöneticilerini işaret etmektedir. Buna göre, kısa aralıklarla takımların başına gelen, genellikle spordan anlamayan yöneticilerin uzun vadede sporcuya ve spora yatırım yapmaktansa derhal başarı elde etmeyi istemeleri, sporcu ve antrenörleri dopinge itmektedir.

"Yönetimler de çok kısa süreli olarak kulüplerin başına geliyor, özellikle futbolda bu daha çok bariz bir şekilde ortaya çıkıyor. Çok kısa süreli ve başarı odaklı geliyorlar. Bu nedenle de başarılı olmak için her türlü yolu denemekten kaçınmıyorlar."..."Bilinçsiz olduğumuz zamanlarda çok kısa bir süre de olsa dopingle ilgili hatalarımız oldu... Başımızdaki yöneticilerin kazanmak adına sporcusunu yönlendirmesinin etkisinde biz de kaldık." (U2).

Benzer şekilde, U8'e göre, bazı branşlarda sporcular yöneticilerin dopingi teșvik ettiğini düşünmektedir, çünkü doping kullandırmış antrenörler federasyonların üst kurullarında görev almaktadır.

\section{Neler Yapılmalı?}

\section{Eğitim}

Katılımcılar, dopingin zararları ve doğurduğu ahlaki problemlere ilişkin verilecek sürekli eğitimlerin dopingi engellemede önemli olacağını vurgulamaktadır. Örneğin $U 1$, bu eğitimlerin kulüpler ve spor bilimleri fakültelerinin yanı sıra ortaöğretimde de yapılması gerektiğini savunurken, bu konuda bir gözlemini de paylaşmaktadır: "Çünkü en son U14-15 grubunda 
yaptığım bir çalışmada bu yaştaki çocukların ilaç kullandığını gördüm ve piyasa adı yazıyordu."

Sporda ahlaki gelişimin öneminden bahseden U4 ve U10 şunları söylemektedir: "Altyapılardan itibaren ahlaki gelişim ve karakter eğitimi gibi programların oluşturulmasının önemli olacağını düşünüyorum." (U4). "Herkesin, kazanılmış başarının gururla savunulabilecek bir başarı olması gerektiğinin farkında olması gerekiyor, küçük yaştan itibaren." (U10).

U5, beden eğitimi bölümlerinde anti-doping derslerinin başlı başına bir ders olarak da verilmesi gerektiğini söylemektedir. U4'e göre ise, "Spor kültürünü ve fair-play duygusunu çocuklara vermemiz ve bunun üzerinden yetiştirmemiz gerekiyor." Benzer şekilde U2 de çocuk yaştan başlayacak eğitimin önemini anlatmaktadır: "Çocuklara ta ilkokuldan başlayarak sporun ne olduğu, ne olması gerektiği anlatılır ve bu eğitim verilirse yukarıya geldiği zaman çocuk kendisi doping yapmaya tevessül etmez... Başarının sporda başarılı olmak değil, sağlıklı bir hayat sürmek olduğunu çocuklara öğretmemiz gerekiyor." (U2).

Uzun yıllar milli takım antrenörlüğü de yapmış olan U3, dopingin zararları hakkında bilgilendirmenin önemini şu cümlelerle anlatmaktadır: "80'li yillarda Alman Atletizm Federasyonundan bir profesör geldi: Manfred Steinbach. Tıp profesörü ama zamanında sekiz küsur metre uzun atlayan bir atlet. Sonra bu hoca Alman Atletizm Federasyonu Başkanı da oldu. O bize bir gün doping üzerine bir seminer yaptı burada. Ben ilk defa orada dinledim. Tabii bilen biri anlattığ için emin ol şoke oldum. Adam kademe kademe dopingin nereye varacağını öyle güzel anlattı ki 'valla dedim, bunu bildikten sonra bunu yapan adam intihar ediyor demektir'. 0 açıdan eğitim etkili oluyor." (U3).

Katılımcılara göre, özellikle antrenörlere, dopinge başvurulmadan, kaliteli antrenmanlarla da sporcuların başarılı olacağının öğretilmesi gerekmektedir. "Yapılan dopinglerin çok daha etkilisi, mesela bir ısınma içinde yapılabilecek basit bir fizyolojik manipülasyon, EPO dopinginin yarattığı oksijen kullanımı artışı etkisinden daha büyük bir etki yapabilir." (U8).
Katılımcıların çoğuna göre, antrenman bilimi bakımından yetersiz olan antrenörlerin ve onlara bel bağlayan yöneticilerin ise sporcuların yetiştirilmesinden ellerini çekmesi sağlanmalıdır. Bununla birlikte, örneğin U4; gelişim, eğitim ve öğrenme psikologlarının; öğretmen ve antrenörlerin çocuk sporculara aileleriyle işbirliği içerisinde eğitim götürmek zorunda olduklarını düşünmektedir.

\section{Ödül Yönetmeliğinin Değişmesi}

Katılımclların ortak düşüncesi ödül yönetmeliğinin değiştirilerek, sporculara verilecek maddi ödüllerin makul düzeylere çekilmesi yönündedir. Bazlları ise, bunu yaparken teşvik edici miktarların çok da altına düşülmemesi gerektiği konusunda da uyarıda bulunmaktadır.

\section{Kontrollerin Arttırılması}

Yarışma sporlarında denetimin arttırılmasını savunan katılımcıların çoğu, fitness merkezlerinde ve mahalle aralarındaki spor salonlarında da polisiye önlemlerin alınması gereğini düşünmektedir. Kendisinin de bir Bağımsız Doping Numune Alıcıları Kurulu (BADNAK) görevlisi olduğunu söyleyen U1, doping kontrollerinin en alt seviyedeki yarışmalara kadar yapılması gerektiğini ve kontrolleri yapan görevlilerin kulüplerle hiçbir bağlantısının olmaması gerektiğini vurgulamaktadır. Benzer şekilde, U2 de denetimlerin daha detaylı ve yaygın bir şekilde yapılması gerektiğini söylemektedir.

U5'e göre; "Antrenmanların yapıldığı salonlarda bir sürü madde alışverişi yapıllyor, ticari anlamda satılıyor ve bunları denetleyen kimse yok! Yani, bu çocukların hayatları ciddiye alınmıyor. $\mathrm{Bu}$ salonların mutlaka denetlenmesi lazımdır." U5, fitness merkezlerinde satılan maddelerin içerisine uyuşturucu gibi bağımlılık yapan maddelerin karıştırıldığını ve çocukların bunlara alıştırıldığını; bu nedenle, bu merkezlerin denetiminin acilen yapılması gerektiğini düșünmektedir. Benzer görüşler aşağıdaki gibidir:

"Üretildiği nokta neresi olursa olsun her türlü kimyasalın üretimine de sınırlama ve adresleme getirilerek oradan da engellemek mümkün olabilir. Tabi ki merdiven altı ve kaçak şekilde dünya kadar şey üretilecektir. Yani üretim koşul- 
larının da kontrol altına alınması gerekmektedir." (U10).

“Türkiye'de dopinge karşı mücadele yaygınlaşmalıdır ve her zaman sporcuların denetim altında olması gerekir. Her sporcunun spora başladığı andan itibaren bu konuyla ilgili seminerler ve sürekli eğitimler verilmeli. Belirli bir düzeye geldiği andan itibaren de her bir sporcunun doping biyometrisi olmall. Yani bir doping kaydı olması lazım. Yani çocuk bilmelidir ki doping maddeleri şunlardır ve bunları kullandığı anda o yarışmalarda aldığı dereceler elinden alınır. Ve hatta ömür boyu da diskalifiye edilebilir." (U7).

\section{Yönetimlerin Spor Uzmanlarından Oluşması}

Spor kulüpleri, federasyonlar ve gençlik ve spor bakanlığındaki yönetimlerin sporun içinden gelen yetkin insanlardan oluşması gerektiğini söyleyen katılımcılar, böylece sporcuların yetiştirilmesinin bilimsel bir nitelik kazanacağını ve dopinge başvurmanın önüne geçileceğini savunmaktadır.

"Kulüp yönetimlerinin uzun vadeli olması ve para verdikleri için yönetici olan kişilerden uzak durulması, yani sporu bilen kişilerin yönetici olması ve kulüplere yöneticilerin para vermemesi... Kısa süreli gelen yöneticiler çok büyük paralar harcadıkları için hemen büyük başarılara gitmek için bu yollara tevessül ediyorlar." (U2).

"Birkaç dönem önceki federasyon başkanı arkadaşın döneminde çok yaygınlaştı. Hatta ben uyarmıştım da onu. Sonra federasyon olarak uluslararası yarıșmalardan men durumuna gelmek üzereydik. İște başkan değiștirildi o zaman. Yeni bir arkadaş geldi. Bu arkadaş doping konusunda sıfır tolerans diye başladı. Ve bence bayağı da yol aldı." (U3).

\section{Devletin Daha Etkin Olması}

Dopingin çok yönlü bir mücadeleyle Türkiye'de spordan silinebileceğini düşünen uzmanlar, bu mücadelede devletin çok etkin bir rol almasını vurgulamaktadır. Bu noktada, uzmanların çoğuna göre, Milli Eğitim Bakanlığı, Gençlik ve Spor Bakanlığı, federasyonlar, spor hekimlikleri, spor fakülteleri ve emniyet birimlerinin işbirliği içerisinde çalışarak doping sorununun üzerine gitmesi gerekmektedir.

"Özellikle devletin her kademesinin, şimdi burada iște özellikle devreye alt gruplardaki antrenörler, oradaki sağlı personeli, onlar girmeye başlıyor. Onların çok daha iyi kontrol edilmesi ve uzaklaştırılması gerekiyor." (U11). Benzer görüşü, U9 da dile getirmektedir. Ona göre, Türkiye'de birçok yasaklı antrenör var ve bunlara hala görevler verilebiliyor. Federasyonlar madalya kazandıran bu antrenörleri gözden çıkartamıyorlar; ancak, temiz bir spor adına bu kişilerin uzaklaştırılması gerekmektedir. U8 ise, devletin ilgili birimlerinin merdiven altı doping maddesi üretenleri engellemeleri ve özellikle eczaneleri de denetlemeleri gerektiğini vurgulamaktadır.

Bununla birlikte U10, devletin sporu toplumun tüm kesimlerine yayarak yetenekli sporculara ulaşacağını ve böylece dopinge ihtiyaç duyulmayabileceğini düşünmektedir. "Spor daha fazla tabana yayılsa, daha geniş bir popülasyondan sporcu yetiştiriyor olsanız, o zaman bu eleme, sağlıklı eleme durumu daha rahat gerçekleşebilir ve bu konuya yeltenecek insanların sayısı da azalır." (U10).

\section{TARTIŞMA ve SONUÇ}

Yarışma sporlarında doping nedenli bilinen ilk ölüm, 1886'da antrenörü tarafından kendisine striknin verildiği söylenen bisikletçi Atrhur Linton vakasıdır (8). 0 günden günümüze kadar birçok kişi hayatını kaybetse de, dopingin önüne tamamen geçilememiştir. WADA ve ülkelerin çabalarına rağmen bu sorun sporu tehdit etmeye devam etmektedir. Bir araştırmaya göre, bugün WADA'nın öncülüğünde 600'ün üzerinde organizasyon doping ile mücadele etmektedir (9). Bu nedenle, Türkiye'de doping sorunu tartışılırken, uluslararası mücadelede gelinen noktanın da göz önünde bulundurulması gerekmektedir. Çünkü bu problemin bir ülkenin salt kendi çabasıyla çözüme kavuşacağını düşünmek gerçeği yansıtmayacaktır. Doping sorunu topyekûn bir mücadeleyi zorunlu kılmaktadır. 
Bunun yanı sıra, bu araştırmadaki bulgular incelendiğinde, Türkiye'nin doping konusunda önünde çok uzun ve zorlu bir yolun olduğu görülmektedir. Devletin ilgili tüm kurumlarının bu konuya daha ciddi bir şekilde yaklaşması ve ödül yönetmeliğinin mutlaka gözden geçirilmesi gerektiği tartışılmaktadır. Başta, toplumun geneline yayllan bir spor eğitimine ve daha da önemlisi; tüm sporcu, antrenör, spor hekimi ve spor yöneticilerinin iyi bir sporu mümkün kılan şeyin spor ahlakı olduğunu kavramalarına ihtiyaç duyulmaktadır. Bunun yolu da uzun vadeye yayılan, derinlemesine bir spor etiği eğitiminden geçmektedir.

Bunun yanı sıra, U12'nin dopingin Türkiye'de serbest bırakılması ve hatta devlet tarafından desteklenmesi düşüncesini de anlamak gerekmektedir. Zira, dünya sporuna dair ciddi bir inanış da sporcuların çoğunun dopingli olduğu ve doping kullanmayan sporcuların zarara uğradığı yönündedir. Örneğin spor felsefecisi Breivik, atletler arasındaki eşitsizliğin dopingin serbest bırakılmasıyla giderileceğini savunur. Çünkü doping kullanan atletler yakalanamamaktadır. $\mathrm{Bu} \mathrm{da}$, temiz atletlerin aleyhine bir durumdur. Eğer serbest bırakılırsa, herkes dopinge eşit şekilde ulaşabilecek, böylelikle adil bir ortam sağlanabilecektir. Kısacası, dopingli atletleri yakalayamıyorsak doping serbest olmalıdır (10). $\mathrm{Bu}$ düşüncenin hangi bakımlardan sorunlu olduğunu tartışmak mevcut araştırmanın kapsamı dişındadır ve başka bir araştırmada ayrıntılarıyla ele alınmıştır (11).

Aşağıdaki maddelerde görüşmelerden elde edilen veriler ışığında öneriler sunulmaktadır:

-Prim, ödül yönetmeliklerinin değişmesi, sporculara verilen miktarların makul düzeylere çekilmesi;

-Sporculara, çocuk yaştan itibaren spor ahlakına uygun eğitimlerin verilmesi;

-Sporcuların dopingin zararları hakkında sürekli bilgilendirilmesi;

-Antrenörlerin mesleki bilgilerini arttıracak uzun vadeli eğitimlerin verilmesi;

-Sporun toplumun geneline yayılmasi;
-Spor kurum ve kuruluşlarında liyakate bakılması, spordan anlayan ve etik ilkelere bağlı yöneticilerin yönetimlere getirilmesi;

-Doping kontrollerinin yalnızca yarışma sporlarında değil, sağlık için yapılan spor merkezlerinde de yapılması. Gerekirse emniyet güçlerinin de sürece müdahil olması ve doping maddelerini satan kişilere yönelik yaptırımların arttırılması;

-Sporcu ve antrenör ilișkisini denetleyen bir mekanizmanın kurulması;

-Milli Eğitim Bakanlığı, Spor ve Spor Bakanlığı, federasyonlar, spor hekimlikleri, spor fakülteleri ve emniyet birimlerinin işbirliği içerisinde çalışarak doping sorununun üzerine gitmesi gerekmektedir.

Sonuç olarak, Türkiye'de doping sorunu uzun erimli planlar ve güçlü bir irade ile çözüme kavuşturulabilir. $\mathrm{Bu}$ iradenin güçlü temelleri de görüşmeye katılan uzmanlardan birinin başarı hakkındaki söylediğiyle atılabilir:

"Herkesin, kazanılmış başarının gururla savunulabilecek bir başarı olması gerektiğinin farkında olması gerekiyor, küçük yaştan itibaren." (U10).

\section{KAYNAKLAR}

1. Prokop L. The struggle against doping and its history. $J$ Sports Med Phys Fitness. 1970;10(1):45-8.

2. Donohoe T, Johnson N. Foul Play: Drug Abuse in Sport. Blackwell: Oxford, 1986.

3. Todd J, Todd T. Significant events in the history of drug testing and the Olympic Games. In: Wilson W, Derse E, Eds. Doping in Elite Sports: the Politics of Drugs in The Olympic Movement. 1st ed. Champaign, IL: Human Kinetics, 2001. pp. 63-128.

4. Türkiye Dopingle Mücadele Komisyonu. http://www.tdmk.org.tr/vizyon/. Erişim Tarihi: 10 Mayıs 2019.

5. Palinkas LA, Horwitz SM, Green CA, et al. Purposeful sampling for qualitative data collection and analysis in mixed method implementation research. Adm Policy Ment Health. 2015;42(5):533-44.

6. Patton MQ. Qualitative Research and Evaluation Methods. 3rd ed. Thousand Oaks, CA: Sage Publications, 2002.

7. Denzin NK Lincoln YS. Handbook of Qualitative Research. 3rd ed. Thousand Oaks, CA: Sage Publications Ltd., 2005.

8. Mottram DR: A historical perspective of doping and anti-doping in sport. In: Mottram DR, Ed. Drugs in Sport. 4th ed. New York, NY: Routledge, 2005. pp. 2133. 
9. Songün Y, Katkat D, Budak D. Türkiye'deki ulusal spor federasyonlarının doping kontrol uygulamalarının değerlendirilmesi. Ankara Üniv Spor Bil Fak. 2015;13(2):93-102.

10. Breivik G. Sport, gene doping and ethics. In: Tamburrini CM. Tännsjö T, Eds. Genetic Technology and Sport: Ethical Questions. 1st ed. New York, NY: Routledge, 2005. pp. 165-77.

11. Tarakçığlu S. Spor etiği bağlamında gen dopingi. Ege Üniversitesi Sağlı Bilimleri Enstitüsü Sporda Psikososyal Alanlar Anabilim Dalı Doktora Tezi. Ege Üniversitesi: İzmir, 2012. 